\title{
Make better use of provider time in public health clinics
}

\section{Barbara Janowitz}

Follow this and additional works at: https://knowledgecommons.popcouncil.org/departments_sbsr-rh

Part of the Demography, Population, and Ecology Commons, Family, Life Course, and Society Commons, International Public Health Commons, and the Medicine and Health Commons How does access to this work benefit you? Let us know!

\section{Recommended Citation}

Janowitz, Barbara. 2006. "Make better use of provider time in public health clinics," FRONTIERS Program Brief. Washington, DC: Population Council. 


\section{Make Better Use of Provider Time in Public Health Clinics}

\section{unding for reproductive \\ health services is stagnant or declining globally;} yet population projections, particularly in Africa, indicate that the demand for services will increase in the near term. Between 2002 and 2025, for example, the population of women of childbearing age (15-49) is expected to increase by 2 percent annually in subSaharan Africa (U.S. Census Bureau 2004). With this growth will come increased demand for contraception, as well as other reproductive health services such as antenatal care, safe birthing services, and postpartum care for both mothers and children (PRB 2002). Concern about increasing demand for reproductive health services has led program managers to examine the productivity and costs of existing programs. While all programs can advocate for additional funds from their governments and establish or increase prices for services to clients, often they can also use their existing resources more efficiently. Evidence from reproductive health programs across developing countries suggests that service providers are often underutilized. Increasing provider productivity-the time they spend with clients-can permit clinics as well as non-clinical programs to meet increased service
- In coming years, the demand for reproductive health services will increase while resources for providing services stagnate.

\section{Programs can make better use of existing} resources, particularly labor-which is the largest expense in service provision.

\section{Studies show that providers spend less} than half of their time with clients.

- Increasing the time providers spend with clients can allow clinics to provide more clients with existing or new services at very low additional costs.

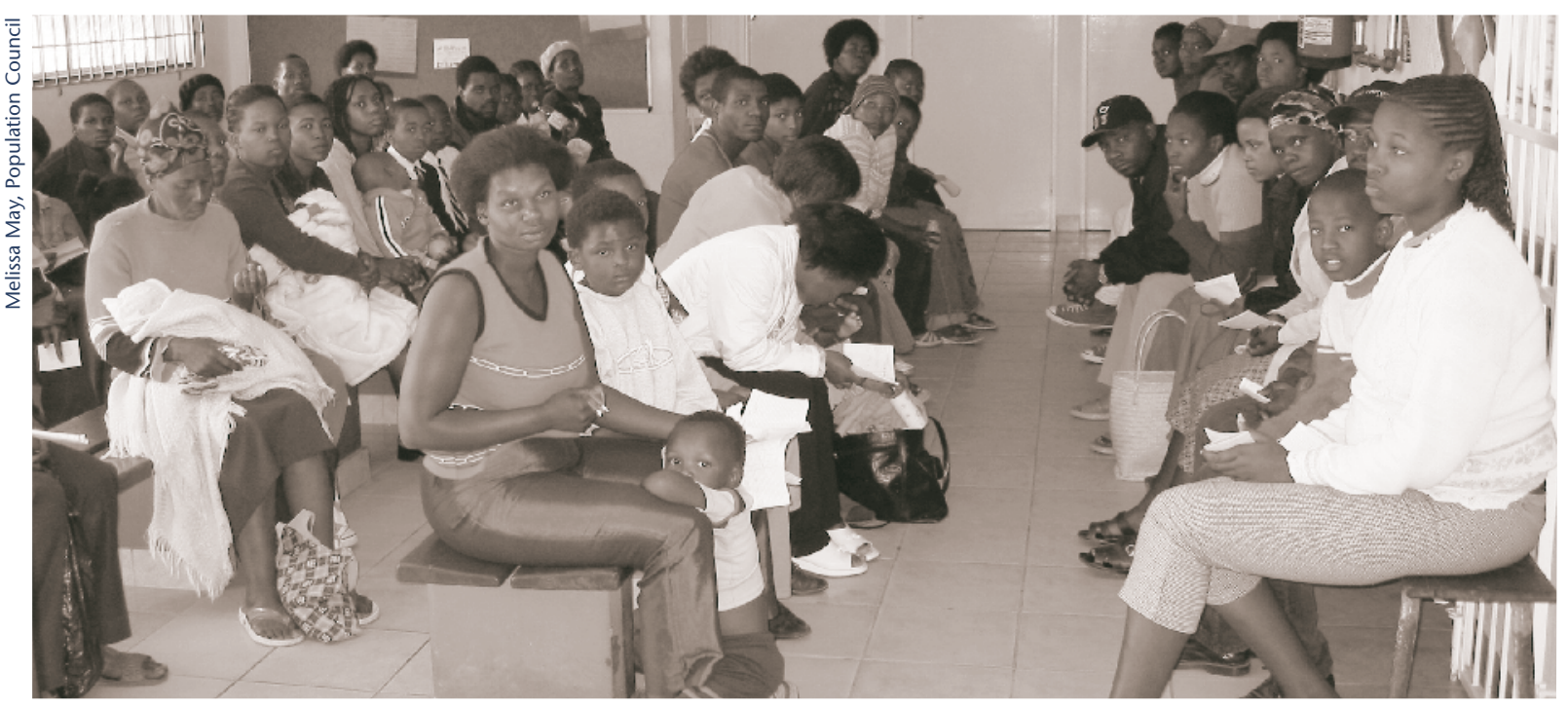

Clients waiting for services at a clinic in South Africa. 


\author{
Frontiers in Reproductive Health \\ Program Brief No. 7 \\ Author: Barbara Janowitz \\ Editors: Laura Raney, \\ Stephanie Joyce \\ Design: Vincent Hughes Visualization \\ (vincent@v-zation.com)
}

The assistance of the following reviewers is appreciated: Patricia Stephenson, Jim Foreit, and John Townsend.

Suggested citation: Janowitz, Barbara. 2006. "Making better use of provider time in reproductive health clinics," FRONTIERS Program Brief No. 7.

Washington, DC: Population Council.

The Frontiers in Reproductive Health Program (FRONTIERS) applies systematic research techniques to improve delivery of family planning and reproductive health services and influence related policies. FRONTIERS is funded by the U. S. Agency for International Development (USAID) and led by the Population Council in collaboration with Family Health International.

This publication was made possible through support provided by USAID under the terms of Cooperative Agreement No. HRN-A-00-98-00012-00.

The opinions expressed herein do not necessarily reflect the views of USAID.

(C) 2006 the Population Council, Inc.

This publication may be reproduced in whole or in part without permission of Population Council provided full source citation is given and the reproduction is not for commercial purposes.

ISSN 1546-6612 demands and enhance quality, even in resource-constrained systems, without requiring significant additional funding.

This Program Brief focuses on provider time use and how programs can make better use of existing labor resources in clinic programs. The data come from

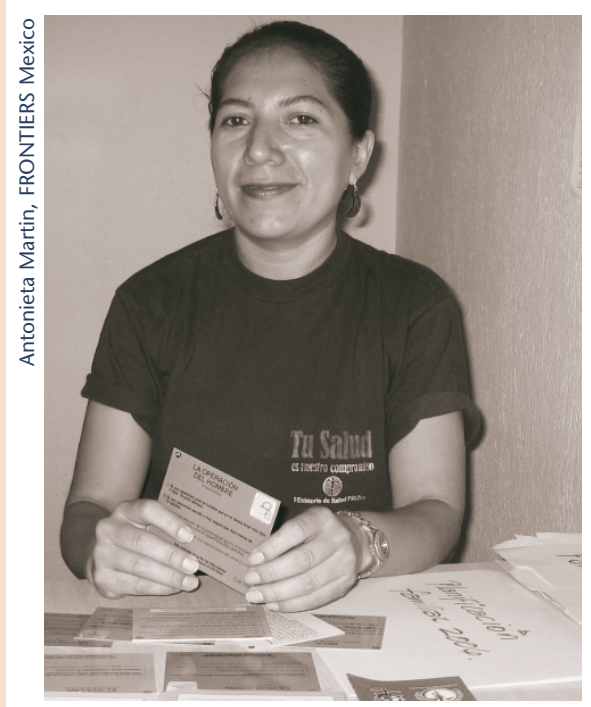

Providers, like this one in Guatemala, spend their day performing multiple tasks.

\section{Contents}

\section{Assessing provider time use}

Time use studies

How providers use time

Provider time use and costs

Improving use of provider time

Distribution of provider time use

Increasing productivity

Conclusions

References
10 time use studies conducted in nine countries in Asia and the Near East, Latin America and the Caribbean, and sub-Saharan Africa.

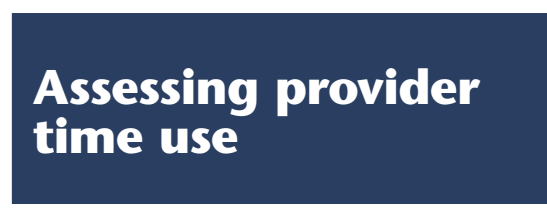

There are two basic methods of measuring provider time use: self-reports-obtained through interviews or self-administered time sheets-and observational studies. One type of observational technique is activity sampling, in which an observer notes what activity a provider is carrying out at fixed intervals or a sample of time. Results are then used to make inferences about how the full day is spent.

\section{Time use studies}

Table 1 provides information on the studies, including the country, year of study, type and number of sites where observation of staff time took place, the number of observed person-days, the purpose of each study, and the reproductive health service focus at the site-family planning (FP), antenatal care (ANC), or voluntary counseling and testing for HIV (VCT). All studies used activity sampling to measure providers' time use in clinics providing reproductive health services. 
Table 1.

Observational studies on provider time use in clinics providing reproductive health services

\begin{tabular}{|c|c|c|c|c|c|}
\hline Country & Year & $\begin{array}{l}\text { Type and } \\
\text { number of } \\
\text { sites }\end{array}$ & $\begin{array}{l}\text { No. of } \\
\text { observed } \\
\text { person- } \\
\text { days }\end{array}$ & Purpose of study & $\begin{array}{l}\text { Service } \\
\text { focus }\end{array}$ \\
\hline $\begin{array}{l}\text { Bangladesh } \\
\text { (Janowitz et al. 1997) }\end{array}$ & $\begin{array}{l}1993- \\
1994\end{array}$ & $\begin{array}{l}16 \text { rural } \\
\text { MOH MCH/FP } \\
\text { clinics }\end{array}$ & 61 & $\begin{array}{l}\text { Determine costs of providing FP } \\
\text { services }\end{array}$ & FP \\
\hline $\begin{array}{l}\text { Ecuador } \\
\text { (Bratt et al. 1999) }\end{array}$ & 1995 & $\begin{array}{l}3 \text { urban } \\
\text { NGO FP clinics }\end{array}$ & 90 & $\begin{array}{l}\text { Test validity of instruments to col- } \\
\text { lect data on time use }\end{array}$ & FP \\
\hline $\begin{array}{l}\text { Zimbabwe } \\
\text { (Janowitz et al. 2002) }\end{array}$ & 1998 & $\begin{array}{l}3 \text { urban } \\
\text { MOH FP clinics }\end{array}$ & 38 & $\begin{array}{l}\text { Determine costs of adding syn- } \\
\text { dromic management to FP services }\end{array}$ & FP \\
\hline $\begin{array}{l}\text { Jamaica } \\
\text { (West et al. 2001) }\end{array}$ & 1999 & $\begin{array}{l}4 \text { urban } \\
\text { MOH MCH } \\
\text { clinics }\end{array}$ & 81 & $\begin{array}{l}\text { Test validity of instruments to col- } \\
\text { lect data on time use }\end{array}$ & FP \\
\hline $\begin{array}{l}\text { Uganda } \\
\text { (Okullo et al. 2003) }\end{array}$ & $\begin{array}{l}2000- \\
2002\end{array}$ & $40 \mathrm{MOH}$ clinics & 447 & $\begin{array}{l}\text { Determine costs and impact of } \\
\text { improving client-provider interac- } \\
\text { tion in FP services }\end{array}$ & FP \\
\hline $\begin{array}{l}\text { Egypt } \\
\text { (SPAAC 2002) }\end{array}$ & $\begin{array}{l}2000- \\
2001\end{array}$ & $24 \mathrm{MOH}$ clinics & 382 & $\begin{array}{l}\text { Determine costs and impact of } \\
\text { improving client-provider interac- } \\
\text { tion in FP services }\end{array}$ & FP \\
\hline $\begin{array}{l}\text { South Africa } \\
\text { (FRONTIERS } \\
\text { unpublished data) }\end{array}$ & $\begin{array}{l}2001- \\
2002\end{array}$ & $12 \mathrm{MOH}$ clinics & 136 & $\begin{array}{l}\text { Determine impact on time use and } \\
\text { costs of adding new services tar- } \\
\text { geted at men in ANC programs }\end{array}$ & ANC \\
\hline $\begin{array}{l}\text { Zambia } \\
\text { (Janowitz et al. 2005a) }\end{array}$ & 2002 & $1 \mathrm{MOH}$ clinic & 25 & $\begin{array}{l}\text { Determine costs of introducing } \\
\text { PMTCT services into ANC services }\end{array}$ & ANC \\
\hline $\begin{array}{l}\text { Kenya } \\
\text { (Janowitz et al. 2005b) }\end{array}$ & 2002 & $2 \mathrm{MOH}$ clinics & 60 & $\begin{array}{l}\text { Determine costs of introducing } \\
\text { PMTCT services into ANC services }\end{array}$ & ANC \\
\hline $\begin{array}{l}\text { Kenya } \\
\text { (Reynolds et al. 2003) }\end{array}$ & 2002 & $\begin{array}{l}6 \mathrm{MOH} \text { VCT } \\
\text { centers }\end{array}$ & 25 & $\begin{array}{l}\text { Determine how much time pro- } \\
\text { viders could make available for FP } \\
\text { counseling or provision }\end{array}$ & VCT \\
\hline
\end{tabular}


Figure 1.

Percent distribution of provider time use at family planning clinics in six countries

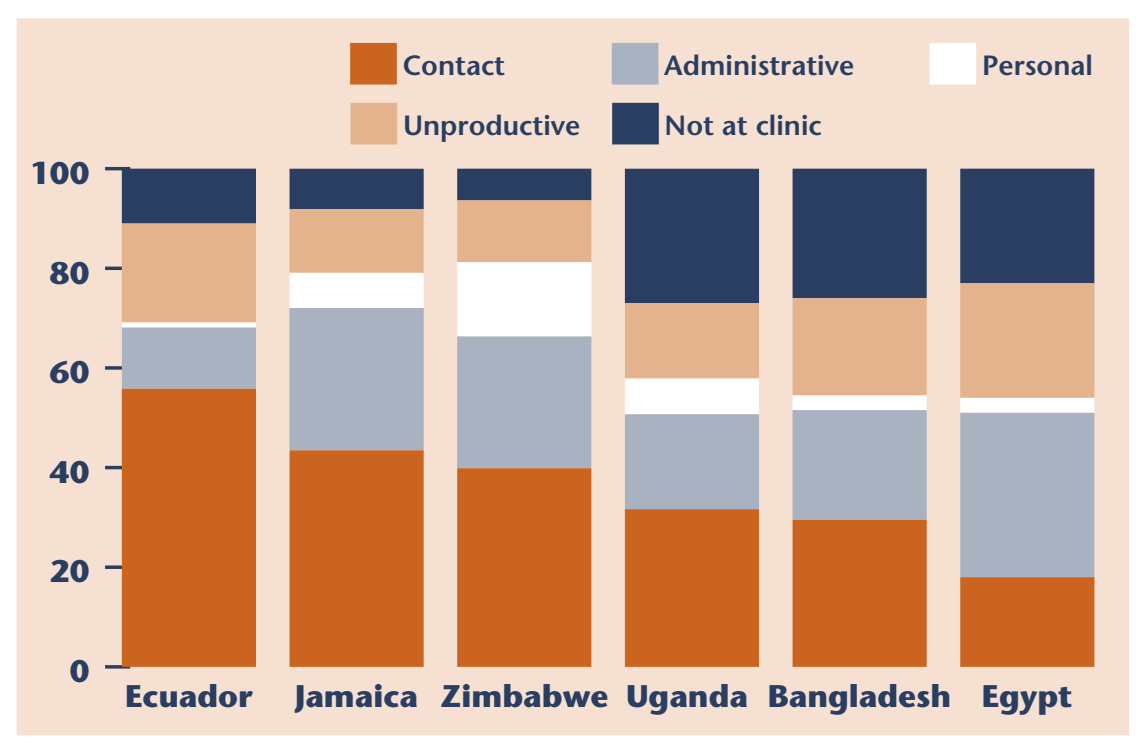

Figure 2.

Percent distribution of provider time use at facilities providing ANC services and VCT services

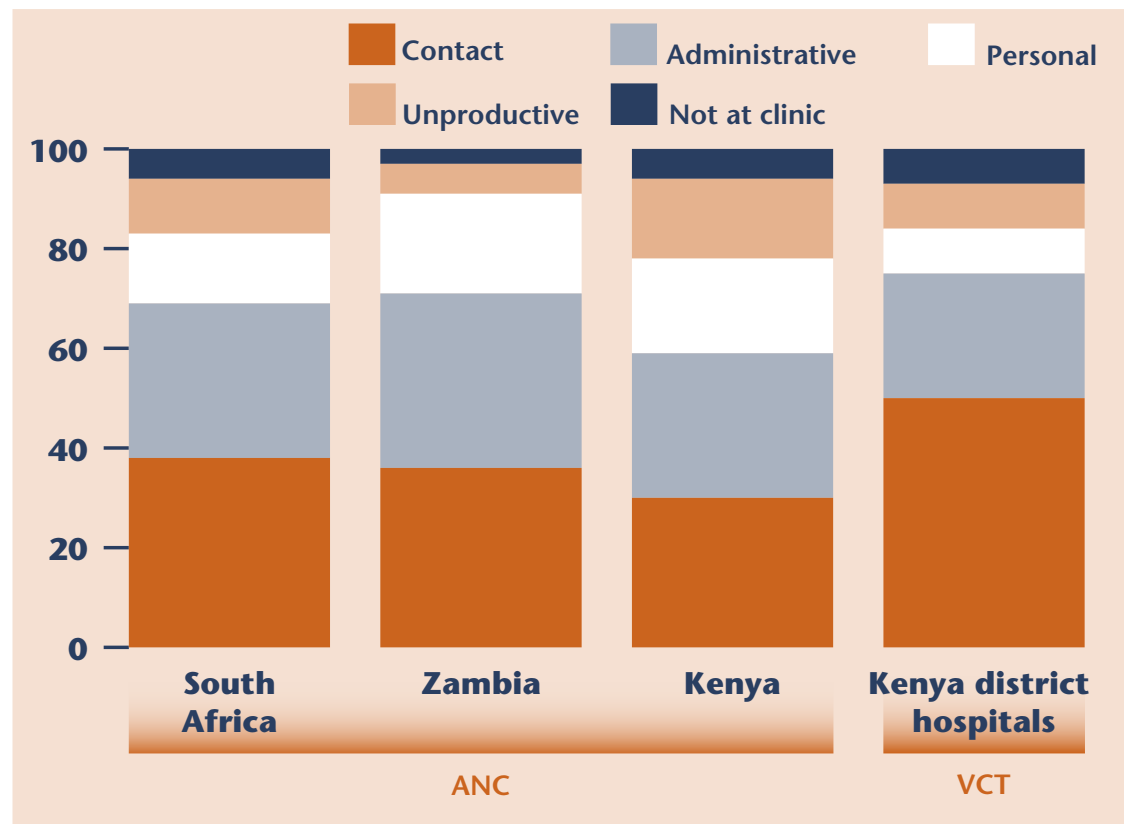

From these 10 studies, data on providers' time use has been classified into the following categories:

- Contact with clients

- Administrative activities, including those that support contact with clients

- Personal time, including meal and tea breaks

- Unproductive time, including waiting for clients or engaging in non-work activities

a Absentee time: absent from the clinic during work hours.

\section{How providers use time}

Figures 1 and 2 show the proportionate distribution of provider time use for the 10 studies included here. Figure 1 illustrates time use at family planning clinics in six countries. The findings show that while time spent with clients (contact) generally accounts for the largest proportion of time, there are wide variations across settings: from a high of 56 percent in Ecuador ${ }^{1}$ to a low of 18 percent in Egypt $^{2}$.

Administrative work generally accounts for the second largest proportion of providers' time, with the exception of Egypt where it is the largest. However, in half of the family planning

1 Providers work split shifts in Ecuador; thus the full workday combines the time of two providers.

2 This calculation is based on a work day of three and a half hours, which is less than the official work day of six hours; however, it is considered to be the actual number of hours that physicians are expected to be at public sector clinics. 
clinics (Uganda, Bangladesh, and Egypt), more than 40 percent of providers' time was spent unproductively or away from the clinic.

Figure 2 shows provider time use at ANC clinics in three countries and one group of facilities providing VCT services, district hospitals in Kenya. Client contact in the ANC clinics was similar to that in the family planning sites (30 to 38\%), but was significantly higher in the VCT centers at district hospitals (50\%). Time spent on administrative tasks was similar to that of the family planning clinics, about one-quarter to one-third of providers' time. Non-productive and absentee time was much lower in the ANC and VCT facilities-less than 20 percent-though personal time was higher.

\section{Provider time use and costs}

A comparison of provider time use in two countries, Zimbabwe and Egypt, illustrates the implications of provider time use on labor costs per client visit (see Table 2). Assuming that providers in Zimbabwe and Egypt work in clinics that have the same capacity (in terms of staff and physical facility), providers in Zimbabwe may be expected to serve about twice as many clients as providers serve in Egypt. This is because providers in Zimbabwe spend about twice as much time with clients (40\%) as those in Egypt (18\%).
Table 2.

Provider time use in reproductive health clinics in Zimbabwe and Egypt (percent)

\begin{tabular}{|c|c|c|}
\hline \multirow[t]{2}{*}{ Activity } & \multicolumn{2}{|c|}{ Percent of time per day (\%) } \\
\hline & Zimbabwe & Egypt \\
\hline Contact with clients & 40 & 18 \\
\hline Administrative & 27 & 33 \\
\hline Personal & 15 & 3 \\
\hline Unproductive & 12 & 23 \\
\hline Not at clinic & 6 & 23 \\
\hline Total time & 100 & 100 \\
\hline
\end{tabular}

Source: Janowitz et al. 2002; SPAAC 2002.

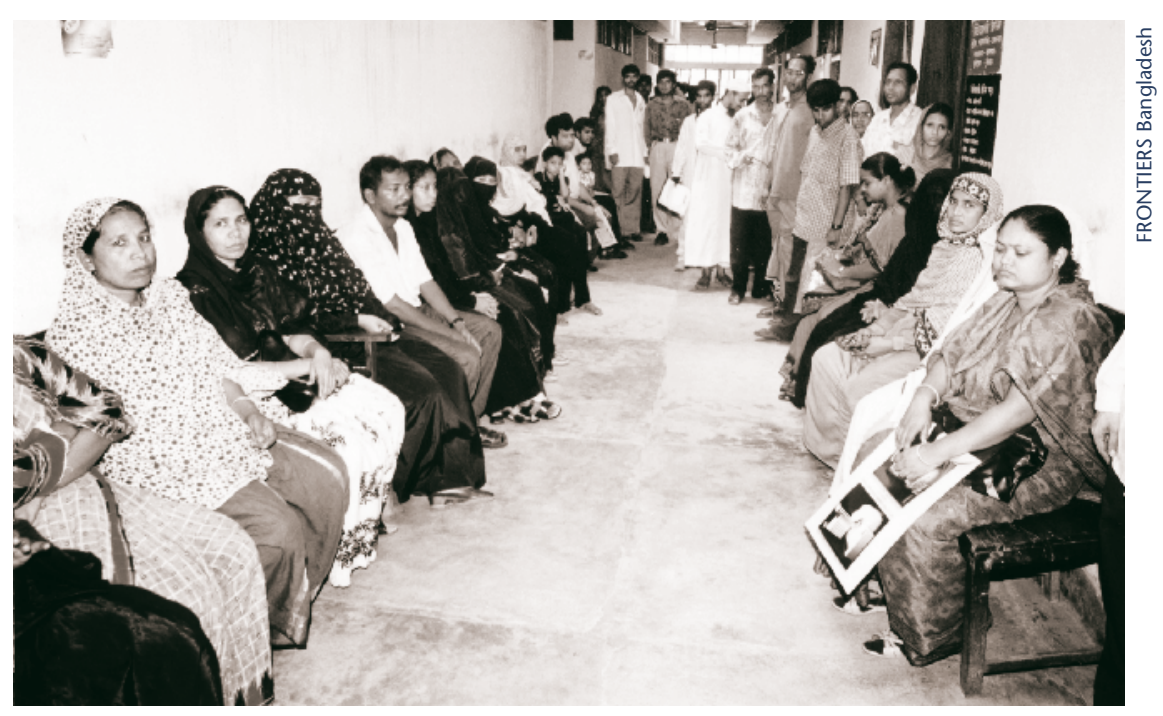

A clinic waiting room in Bangladesh.

Time spent with clients accounts for the largest proportion of providers' time, though there are wide variations according to setting.

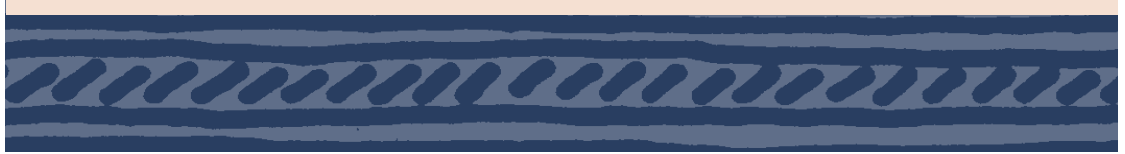


In measuring labor costs, the full labor cost of a family planning visit includes both the cost of the time that providers spend with clients and the cost of the time not spent with clients (prorated indirect costs). From the example above, where providers in Zimbabwe spend about twice as much time with clients as those in Egypt, the labor cost of a visit in Zimbabwe will be about half as much as in Egypt, assuming equal salary levels. Since providers' labor has already been paid for, more intensive use of this resource will spread its costs across a greater number of client visits. In less busy clinics such as in Egypt, the cost per visit is higher since a larger portion of the total wage bill is allocated to each visit. Thus, the salaries of providers in Egypt need to cover both the direct client contact and the roughly 80 percent of the time during which providers are not seeing clients.

\section{Improving use of provider time}

While providers should not be expected to spend all their time with clients, in an ideal situation they would minimize time spent on administrative tasks, waiting for clients (unproductive time), and away from the clinic. Clinics can add new clients for existing or new services at very low additional costs. These addi- tional costs may include only those for supplies associated with visits made by additional clients. Assuming that providers increase the time they spend with clients, it follows that labor costs per visit would decrease if providers attend to more clients. Thus, until the clinic staff reaches full capacity, the added costs of serving additional clients is low.

To improve the productivity of providers, policy makers and program managers should consider the following options:

\section{- Take advantage of the fact that the same client load can be seen in a shorter period of time by closing the clinic periodically and providing community outreach services on that day. For example, some} family planning and other reproductive health services can be provided through mobile posts in the community. In Ecuador, a nongovernmental organization experimented with using excess staff time to offer clinic services one day per week in rural areas and found the model to be effective in certain circumstances, such as the deployment of a mobile clinic during a market day when many potential clients were gathered at one site (Bratt 1999).

\section{Introduce systematic screen- ing to meet multiple client needs during one visit. Multi-} country studies have shown that systematic screening, a simple technique used to identify unmet service needs, can increase the number of services received per client visit by 9 to 35 percent (Foreit 2006) (see Box 1). In feefor-service clinics, more intensive use of staff resources can improve the sustainability of clinic services. New clients for existing and new services will increase revenues, and if the increase in revenues is greater than the increase in costs, the clinic will reduce its financial deficit and enhance its sustainability.

\section{Box 1.}

\section{Systematic screening}

Systematic screening is a simple intervention to increase the number of services received at a single client visit. In this strategy, providers use a checklist or brief questionnaire to identify each client's needs and desires for health services. Then they provide these services during the same visit, through an appointment at the same clinic, or through referral to another facility. Operations research studies in Latin America, Africa, and Asia provide evidence of the benefits of systematic screening in terms of increased services, increased attention to unmet needs, and greater program efficiency. In areas where the unmet need for reproductive health services is high, and provider productivity is low, screening is an effective and cost-effective alternative to outreach services (Foreit 2006). 
Box 2.

\section{Client waiting time}

How providers allocate their time, combined with the clinics' appointment procedures, may also affect how long clients wait to see providers. This may be an issue because in many settings, the long wait is often a major complaint among clients. For example, new antenatal care clients observed in clinics in South Africa spent over four hours obtaining services (Figure 4), with much of that time spent waiting for services, compared to about three hours for returning clients. Clients see many different providers and often spend more time waiting to see the next provider than they spend in contact with that provider. Both new and repeat clients had an especially long wait before seeing the first provider (over 1 hour). In part, this was because clients came early to the clinic knowing that if they did not come early enough they would not be able to receive services. Thus, virtually every woman who received antenatal care had started her first contact by $10 \mathrm{am}$.
Figure 4.

\section{Time spent by new and returning ANC clients wait- ing for providers and in contact with providers, South Africa}

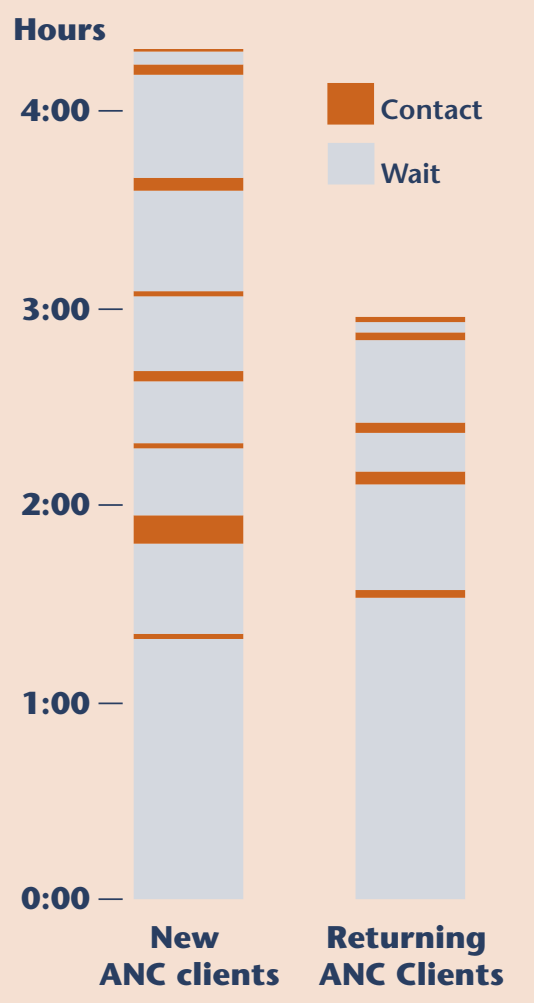

compensation. In resource-constrained settings, the salaries of public health care providers are often quite low. Some providers, particularly physicians, leave clinics early in order to attend to their private practices. Other providers, such as nurses, may not have a financial incentive to leave work early, but may prefer to work hard in the morning and have the afternoons free of client care. Such providers may resent demands that they attend to additional clients. Moreover, research has provided little evidence on providers' motivation or ways to enhance commitment. Several possible strategies to increase providers' productivity may be investigated through operations research:

\section{- Implement a payment sys-} tem that provides additional rewards to providers for contacts that they have with clients during the less busy hours of the day. In this strategy, providers could be paid on a per client basis (in addition to their regular salary) during the less busy hours, such as in the afternoon, while still serving clients during the normal morning hours. This strategy would encourage providers to remain at the clinic during the later afternoon hours and, if the client load increases, could reduce the average labor cost per visit. Though this strategy would increase labor costs as well, instituting an in-reach program such as systematic screening during the less crowded times could potentially raise revenues sufficiently to offset the increase. 


\begin{abstract}
- Provide different services during the afternoon hours, but take care to keep complementary services together. If

clinics are charging for services, such a strategy could lead to an increase in net profits, although fees for the new services would have to cover the extra costs of supplies and possibly training and extra payments to staff.
\end{abstract}

\section{- Pay providers a bonus to work in the community when the clinic is closed or at times when utilization is very low.}

Outreach activities are part of the job of some, but not all providers. Where outreach is not a standard practice, providers may need to be paid a bonus or receive a fee from the clinic for each client served. The effects of this strategy on productivity are unknown, since both the wage costs and output would likely increase.

\section{- Schedule appointments to utilize slower periods.}

Scheduling appointments could reduce waiting time. Incentives could be used to encourage clients to obtain care during less busy periods-for example, where clinics charge for servicesby instituting lower prices during the less busy afternoon hours. This intervention could be combined with changing provider payment schedules as mentioned above.

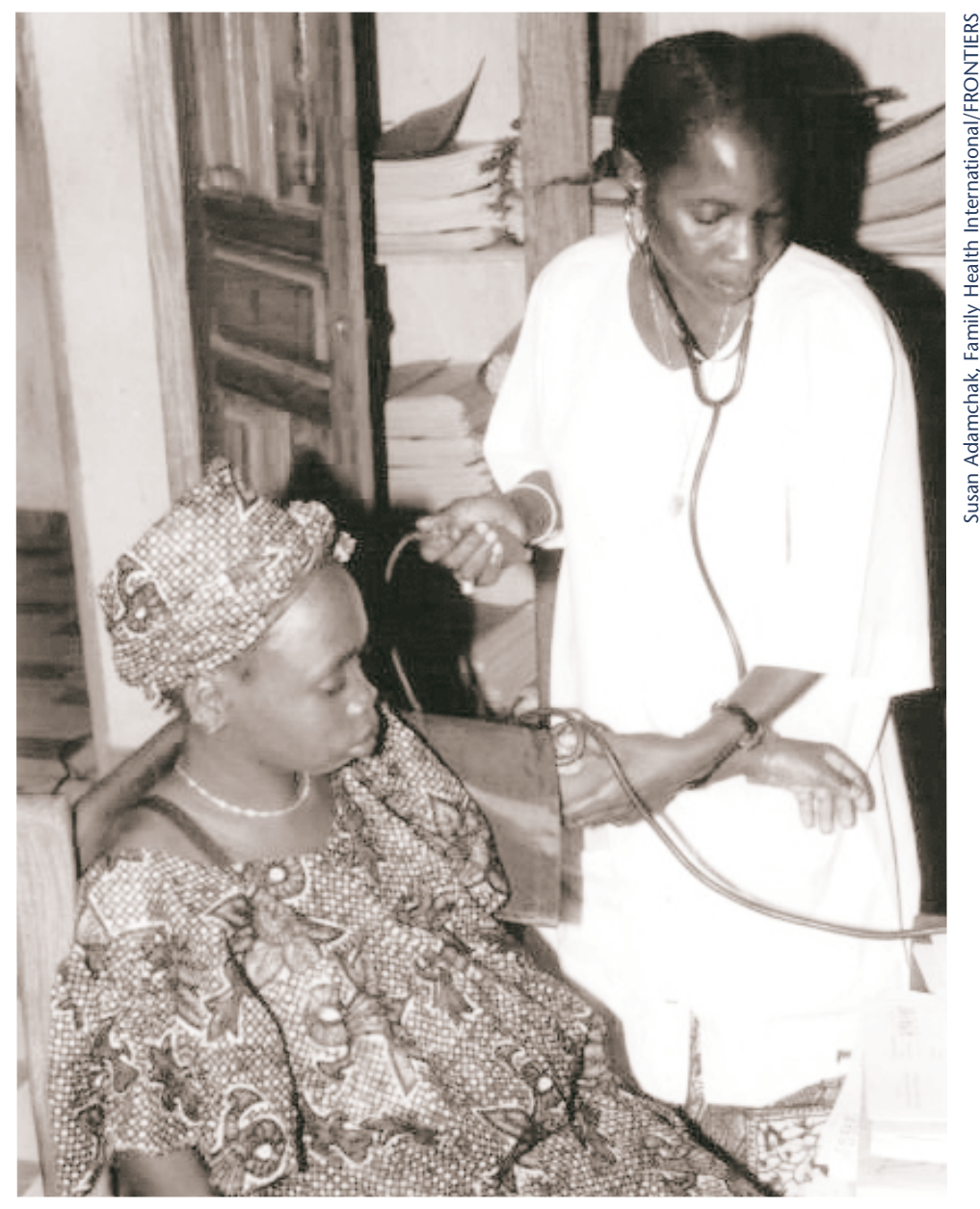

A provider checks a client's blood pressure in Senegal. 


\section{Conclusions}

With increasing numbers of women entering their reproductive years, the demand for clinic-based reproductive health services is growing faster than available resources for providing services. Programs can make better use of existing resources, particularly labor. Research across countries shows that in the majority of clinics, service providers spend less than half their time with clients.

Several suggestions to improve the productivity of providers are given, including offering monetary compensation to reward providers for contacts that they have with clients during the less busy hours of the day or to work in the community when the clinic is closed or times when utilization is very low; adopting systematic screening to identify clients' unmet needs; scheduling appointments; and providing different services during the afternoon hours. Increasing providers' productivity-the time they spend with clients-can permit clinics to provide more

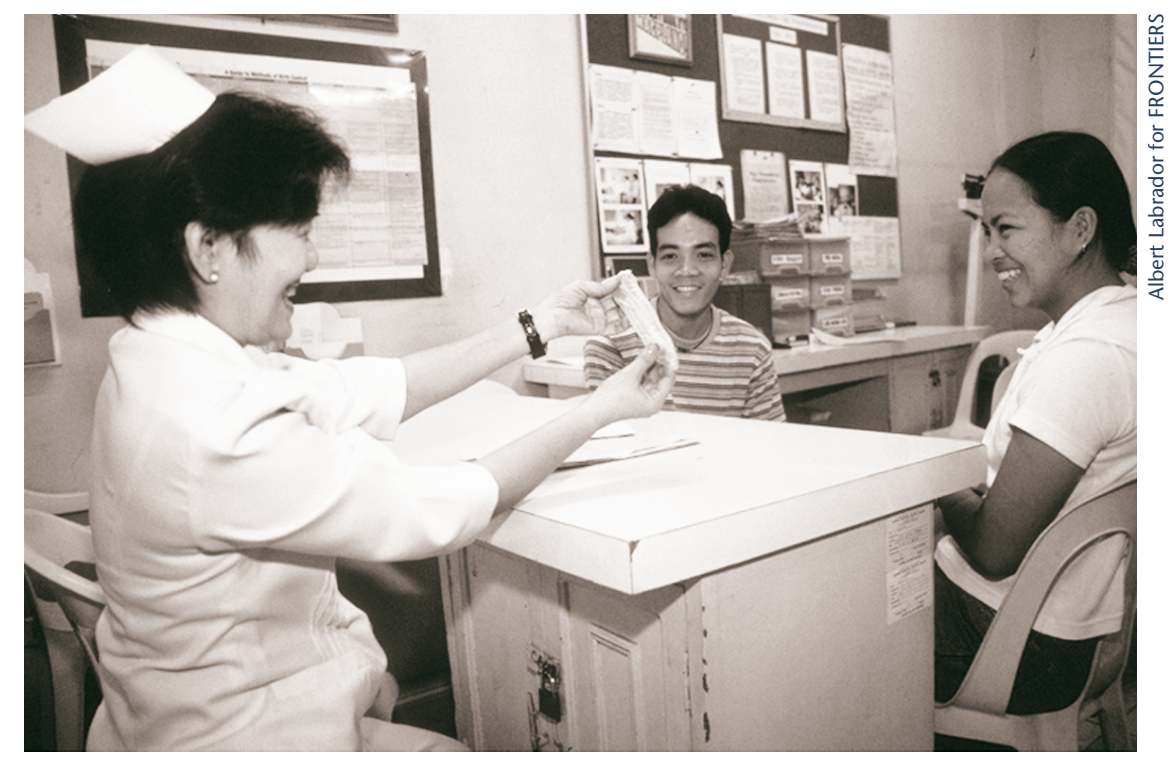

A provider discusses condom use with a couple in the Philippines.

clients with existing or new services at very low additional costs. Depending on prices charged for services, this can add to a clinic's net revenues.

Many low-cost options are available to program managers and policymakers interested in maintaining quality services in the face of increasing demand and stagnant funding. Making better use of provider time in public health clinics can improve services for clients and enhance the financial sustainability of the program.

\section{Making better use of provider time in public health clinics can improve services for clients and enhance the financial sustainability of the program.}




\section{References}

Bratt, John H. et al. 1999. "A comparison of four approaches for measuring clinician time use," Health Policy and Planning 14(4): 374-381.

Cuthbertson, Carmen, Laura Johnson, and Kristin Fox. 2004. "Is a block appointment system feasible for Kingston public sector clinics that provide family planning services? Findings from a pilot study at two clinics in Kingston, Jamaica." Family Health International Report. Research Triangle Park, NC: Family Health International.

\section{Foreit, James R. 2006.}

"Systematic screening: A strategy for determining and meeting clients' reproductive health needs," FRONTIERS Program Brief No. 6. Washington, DC: Population Council.

Janowitz, Barbara, Elan Reuben, Chipepo Kankasa, and Naomi Rutenberg. 2005a. "Cost effectiveness of strategies to prevent mother-to-child transmission of HIV in Lusaka, Zambia." Unpublished Report, Horizons Program/Population Council.
Janowitz, Barbara, Elan Ruben, Ruth Nduati, and Naomi Rutenberg. 2005b. "Cost effectiveness of strategies to prevent mother-to-child transmission of HIV in two sites in Kenya." Unpublished Report, Horizons Program/Population Council.

Janowitz, Barbara et al. 2002. "Excess capacity and the cost of adding services at family planning clinics in Zimbabwe," International Family Planning Perspectives 28(2): 58-66.

Janowitz, Barbara et al. 2001. "How do providers spend their time: Implications for the costs and quality of reproductive health services," paper presented at the 2001 annual meeting of the Population Association of America, Washington, DC, 29-31 March.

Janowitz, Barbara et al. 1997. "Can the Bangladeshi family planning program meet rising needs without raising costs?" International Family Planning Perspectives 23(3): 116-121, 145.

Okullo, Joel et al. 2003.

"Improving quality of care for family planning services in Uganda," FRONTIERS Final Report. Washington, DC: Population Council.

Population Reference Bureau. 2002. "Securing future supplies for family planning and HIV/ AIDS prevention," MEASURE Communication Policy Brief. Washington, DC: Population Reference Bureau.
Reynolds, Heidi, Jennifer Liku, and Ndugga Baker Maggwa. 2003. "Assessment of voluntary counseling and testing centers in Kenya," Family Health International Final Report. Research Triangle Park, NC: Family Health International.

Social Planning Analysis \& Administration Consultants (SPAAC). 2002. "Impact of improved client-provider interaction on women's achievement of fertility goals," FRONTIERS Report. Washington, DC: Population Council.

\section{U.S. Census Bureau,} International Programs Reports WP/02. 2004. Global Population Profile: 2002. Washington, DC: U.S. Government Printing Office.

West, Caroline et al. 2001. "Measuring staff time use in public sector family planning clinics in Kingston Jamaica: A comparison of four methods," Family Health International Final Report. Research Triangle Park, NC: Family Health International.

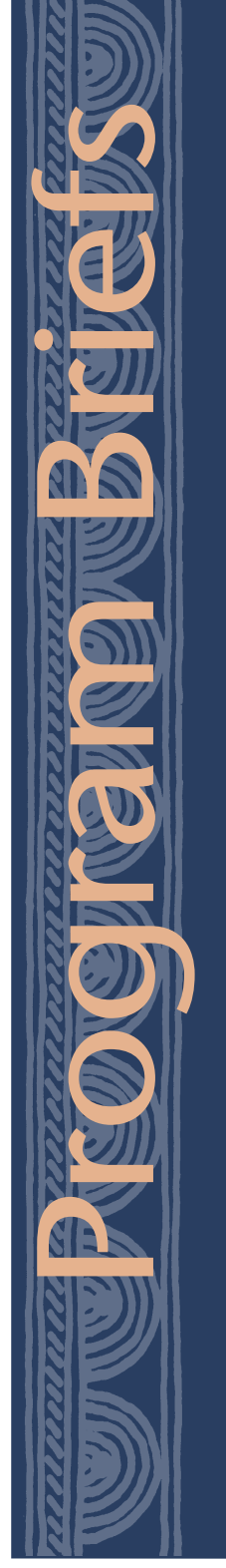


The Population Council is an international, nonprofit, nongovernmental institution that seeks to improve the well-being and reproductive health of current and future generations around the world and to help achieve a humane, equitable, and sustainable balance between people and resources. The Council conducts biomedical, social science, and public health research and helps build research capacities in developing countries. Established in 1952, the Council is governed by an international board of trustees. Its New York headquarters supports a global network of regional and country offices.

The Frontiers in Reproductive Health Program (FRONTIERS) applies systematic research techniques to improve delivery of family planning and reproductive health services and influence related policies. FRONTIERS is funded by the U.S. Agency for International Development (USAID) and led by the Population Council in collaboration with Family Health International.

Frontiers in Reproductive Health Program (FRONTIERS) Population Council

4301 Connecticut Avenue, NW, Suite 280

Washington, DC 20008

Telephone: (202) 237-9400

Facsimile: (202) 237-8410

E-mail: frontiers@pcdc.org www.popcouncil.org/frontiers

This publication was made possible through support provided by USAID under the terms of Cooperative Agreement No. HRN-A-00-98-00012-00. The opinions expressed herein do not necessarily reflect the views of USAID.

(C) 2006 the Population Council, Inc.

This publication may be reproduced in whole or in part without permission of Population Council provided full source citation is given and the reproduction is not for commercial purposes. 